\title{
Changes in milk fatty acid composition of goats during lactation in a semi-intensive production system
}

\author{
CENGIZ ATAŞOĞLU' ${ }^{1}$, ÇiĞDEM UYSAL-PALA ${ }^{2}$ and YONCA KARAGÜL-YÜCEER ${ }^{2}$ \\ 'Department of Animal Science, Faculty of Agriculture, Çanakkale Onsekiz Mart University, Çanakkale, Turkey, \\ ${ }^{2}$ Department of Food Engineering, Faculty of Engineering and Architecture, Çanakkale Onsekiz Mart University, \\ Çanakkale, Turkey
}

\section{Abstract}

This study aimed at investigating changes in the fatty acid (FA) profile and conjugated linoleic acid (CLA) concentration of milk fat during lactation from goats managed in a semi-intensive production system, which consisted of grazing on a woody and herbaceous pasture with the supplementation of mixed concentrate and vetch hay. A total of 21 lactating goats were used. Milk samples were collected at different periods (25 April, 29 June, 25 August and 4 October) during lactation and analysed for their chemical composition and FA profile. The most abundant FA in the milk fat of goats was palmitic (C16:0) acid, followed by oleic (C18:1 $n-9$ ), stearic (C18:0), capric (C10:0) and myristic (C14:0) acids. These acids accounted for about $88 \%$ of the total milk FA of goats in all sampling periods. The two medium chain $\mathrm{FA}$; capric $(P=0.0001)$ and lauric $(\mathrm{C} 12: 0 ; P=0.0014)$ acid were affected by the sampling period, whereas myristic $(P=0.4469)$ and palmitic $(P=0.4418)$ acids did not change. Stearic $(P=0.0128)$, oleic $(P=0.0001)$, linoleic ( $C 18: 2$; $P=0.0088)$ and linolenic ( $(18: 3 ; P=0.0001)$ acids also exhibited significant variations between the sampling periods. However, the CLA (C18:2 C9, t11 and C18:2 t10, c12) contents of milk fat did not change during the entire study regardless of the sampling period $(P=0.2448)$. Milk fatty acid composition of goats, which meet a major part of their nutrient requirements through grazing or browsing in a natural pasture, shows a seasonal variation with milk fat in summer representing a better fatty acid profile for product quality.

Keywords: goat milk fat, shrubland, fatty acid composition, linoleic, linolenic, PUFA, conjugated linoleic acid

\section{Zusammenfassung}

\section{Veränderungen des Fettsäuremusters von Ziegenmilch während der Laktation in einem semi-intensiven Produktionssystem}

Es wurden die Veränderungen des Milchfettsäuremusters (FA) und der konjugierten Linolsäure (CLA) während der Laktation bei 21 Saanenziegen in einer semiintensiven Ziegenhaltung untersucht. Den Tieren standen auf der Tagweide überwiegend Sträucher und Wiesenkräuter zur Verfügung und sie erhielten ergänzend im Stall kommerzielles Kraftfutter und Wickenheu. Die Milchproben wurden an vier Beobachtungstagen nämlich am 25.4., 29.6., 25.8. und 4.10. erfasst. Den höchsten Fettsäureanteil hatte die Palmitinsäure 
(C16:0) gefolgt von Ölsäure (C18:1 n-9), Stearinsäure (C18:0), Caprinsäure (C10:0) und Myristinsäure (C14:0). Bei allen Probezeiten betrug der Anteil dieser Fettsäuren etwa $88 \%$. Einen signifikanten Einfluss hatte der Probetag auf die beiden mittelkettigen Fettsäuren wie Caprin- (C10:0) und Laurinsäure (C14:0), während bei der Myristin- und Palmitinsäure keine Unterschiede zwischen den Beobachtungstagen festgestellt wurden. Auch bei der Stearin-, Öl-, Linol- und Linolensäure wurde ein signifikanter Einfluss des Beobachtungszeitpunktes nachgewiesen. Keine Veränderungen während der Laktation wurden bei den CLA festgestellt. Unter den gegebenen Weidebedingungen zeigten sich saisonale Schwankungen im FA Muster bei einer Verbesserung der Milchqualität im Sommer.

Schlüsselwörter: Ziege, Milchfett, Sträucherweide, Fettsäuremuster, Linolsäuren, Linolensäuren, PUFA, konjugierte Linolensäure

\section{Introduction}

Milk from goats is of particular nutritional and economic importance in many parts of the world. Goat milk is primarily used for the production of traditional cheeses, yoghurt and ice-cream. The composition of milk is one of the major factors determining its value in the market. The nutritive value and technological properties of milk are largely influenced by its composition (MORAND-FEHR et al. 2007). A number of animal (species, breed) or environmental (feeding regime, lactation stage, animal health and management) factors affect milk composition (LEIBETSEDER 1996, WOJTOWSKI et al. 2001, CHILLARD et al. 2003, GORECKI et al. 2004).

Lipid composition is one of the crucial components of milk from the nutritional point of view. Ruminant milk and meat contain relatively higher amounts of saturated fats than most oils of plant origin. The consumption of saturated fats is often associated with health disorders in man, such as coronary heart disease (PFEUFFER 2001). Efforts have therefore been directed to manipulate fatty acid (FA) composition of ruminant milk and meat. In this regard, the influence of changes in diet composition on milk FA profile of goats has been extensively studied (MIR et al. 1999, NUDDA et al. 2003, CHILLARD and FERLAY 2004). Lipid supplementation of the diet, for example, has been shown to alter FA profile by improving the amounts of unsaturated FA including conjugated linoleic acids in milk, which have health-enhancing properties (CHILLARD et al. 2003, WALISIEWICZNIEDBALSKA et al. 2004). However, the number of studies focusing on FA composition of milk from goats, which meet a major part of their nutrient requirements through grazing or browsing in the pasture, is scarce (TSIPLAKOU et al. 2006, D'URSO et al. 2008). This is of particular significance to the sustainability of goat farming systems, depending very much on grazing, which plays an ecological role and contributes to the production of special dairy products such as cheese. This study was, therefore, undertaken to investigate changes in milk FA composition of goats in a semi-intensive production system mainly based on grazing on a woody and herbaceous pasture. 


\section{Material and methods}

\section{Goats and pasture}

The present study was carried out with twenty one (2-4 years old) lactating Saanen goats at the Technological and Agricultural Research Centre of Çanakkale Onsekiz Mart University, which is located in Northwest of Turkey. Body weight of goats was monitored by weighing at sampling periods. Body condition score (BCS) was taken by an expert using a BCS scale of 1 (thin) to 5 (fat). Dairy goat production in the research centre is based on a semi-intensive system in which the nutrition of goats was based mainly on grazing on a woody and herbaceous pasture. The wooded pasture of the study area consisted mostly of species such as Pyrus elaeagrifolia, Prunus amygdalus, Phillyrea latifolia, Quercus coccifera, Ulmus glabra and Pinus pinaster. The pasture was located at an altitude of $36 \mathrm{~m}$. The average rainfall of the area was $505 \mathrm{~mm}$ in the study year. The goats received a total of $1.0 \mathrm{~kg}$ ( $0.5 \mathrm{~kg}$ each milking) mixed concentrate before morning and evening milking. Vetch hay was also offered for ad libitum intake to the goats in the barn.

Table 1

Chemical compositions of tree species, pasture grass, mixed concentrate and vetch hay used by the goats ${ }^{1}$ Nährstoffzusammensetzung des Ziegenfutters - Sträucher, Grünland, Kraftfutter und Wickenheu

\begin{tabular}{lcccccc}
\hline & $\mathrm{DM}, \mathrm{g} \mathrm{kg}^{-1}$ & $\mathrm{CP}, \mathrm{g} \mathrm{kg}^{-1} \mathrm{DM}$ & $\mathrm{EE}, \mathrm{g} \mathrm{kg}^{-1} \mathrm{DM}$ & $\mathrm{NDF}, \mathrm{g} \mathrm{kg}^{-1} \mathrm{DM}$ & $\mathrm{Dsh}, \mathrm{g} \mathrm{kg}^{-1} \mathrm{DM}$ & $\mathrm{CT}, \mathrm{g} \mathrm{kg}^{-1} \mathrm{DM}$ \\
\hline Pyrus & 637.5 & 97.2 & 79.0 & 389.1 & 70.8 & 120.9 \\
elaeagrifolia & $(550.3-696.2)$ & $(78.3-110.0)$ & $(46.4-115.6)$ & $(327.5-466.3)$ & $(63.5-76.0)$ & $(44.5-184.2)$ \\
Prunus & 591.0 & 119.7 & 87.8 & 326.4 & 118.6 & 61.2 \\
amygdalus & $(446.4-783.5)$ & $(97.6-153.7)$ & $(49.6-118.2)$ & $(273.8-384.0)$ & $(85.3-148.8)$ & $(27.6-83.4)$ \\
Phillyrea & 767.0 & 79.4 & 164.3 & 416.3 & 49.4 & 19.9 \\
latifolia & $(681.7-903.2)$ & $(73.9-85.5)$ & $(135.9-201.0)$ & $(373.8-478.1)$ & $(45.9-51.6)$ & $(13.4-29.5)$ \\
Quercus & 693.4 & 83.0 & 77.3 & 483.6 & 50.6 & 91.7 \\
coccifera & $(580.9-848.2)$ & $(74.6-94.4)$ & $(57.1-98.4)$ & $(401.1-535.7)$ & $(46.7-54.8)$ & $(58.5-138.2)$ \\
& 653.2 & 128.0 & 58.3 & 443.7 & 146.4 & 138.4 \\
Ulmus glabra & $(546.5-816.4)$ & $(110.6-168.4)$ & $(44.4-76.1)$ & $(321.7-535.2)$ & $(96.4-202.7)$ & $(104.8-215.2)$ \\
& 566.7 & 77.8 & 111.6 & 530.0 & 38.3 & 150.1 \\
Pinus pinaster & $(485.4-681.4)$ & $(64.0-87.8)$ & $(97.3-125.7)$ & $(515.6-541.6)$ & $(33.7-45.7)$ & $(128.7-218.5)$ \\
& 524.5 & 81.5 & 61.3 & 550.8 & 113.3 & 24.0 \\
Pasture grass & $(270.1-901.9)$ & $(53.7-109.3)$ & $(38.0-82.5)$ & $(480.3-674.8)$ & $(85.1-166.2)$ & $(23.2-24.9)$ \\
& & & & & & \\
Mixed & 947.8 & 189.8 & 25.2 & $\mathrm{nd}$ & 84.0 & $\mathrm{nd}$ \\
concentrate & & & & & & \\
Vetch hay & 958.9 & 149.1 & 9.7 & 465.2 & 87.6 & $\mathrm{nd}$ \\
\hline
\end{tabular}

'Results are the means of samples of the tree species and pasture grass from four sampling dates (25 April, 29 June, 25 August and 4 October). Values in parentheses are the minimum and maximum seasonal means of the species. DM dry matter, CP crude protein, EE ether extract, NDF neutral detergent fibre, CT condensed tannin, nd not determined

The nutritional compositions of the leaves and shoots of the dominant tree species and grass samples (representing the pasture's botanical composition, which was collected by cutting four quadrants $(50 \times 100 \mathrm{~cm})$ to ground level with scalpels) were determined at four harvest dates (25 April, 29 June, 25 August and 4 October 2006) just to describe the 
basic nutrient composition of the pasture on which the goats grazed throughout the study. All feed samples were analysed according to the methods of AOAC (2000) for dry matter (method 930.15), crude protein (method 990.03), neutral detergent fibre (NDF, expressed inclusive residual ash; VAN SOEST et al. 1991), ether extract (method 2003.05) and ash (method 942.05). Condensed tannin (CT) was determined by butanol-HCl method as described by MAKKAR et al. (1995). All chemical analyses were carried out in triplicate. The goats had free access to water and mineral block during the study (Table 1).

\section{Milking}

Milk samples (0.5l/goat) for chemical composition and FA analyses were taken on 25 April ( $88 \pm 13$ days of lactation), 29 June (153 \pm 13 days of lactation), 25 August ( $210 \pm 13$ days of lactation) and 4 October ( $250 \pm 13$ days of lactation) from each goat after mixing the yield from the evening and morning milking. Milk samples were collected in plastic containers and transferred to the laboratory immediately. They were kept in a refrigerator at $4^{\circ} \mathrm{C}$. The basic composition of milk samples was determined approximately 3-4 $\mathrm{h}$ after milking. The remainder of milk samples were further processed for free FA (FFA) analysis.

\section{Basic composition}

Milk was analysed for fat, protein, lactose and solids-non-fat by an ultrasonic milk analyser (LACTOSCAN Milk Analyzer, Milkotronic Ltd, Nova Zagora, Bulgaria).

\section{Free fatty acid analysis}

Twenty-five millilitres of milk were centrifuged at $12557 \mathrm{~g}$ for $30 \mathrm{~min}$ at $5^{\circ} \mathrm{C}$. One gram sample from the fat fraction of the centrifuged milk samples was transferred into a micro tube and centrifuged at $14737 \mathrm{~g}$ for $20 \mathrm{~min}$ at $28^{\circ} \mathrm{C}$. Upper fraction was retained for methylation in $2 \mathrm{ml}$ amber vials. The vials were capped under inert $\mathrm{N}$ gas and stored at $-30^{\circ} \mathrm{C}$ (FENG et al. 2004, LUNA et al. 2005).

\section{Methylation}

Forty milligrams fat sample were dissolved in $1 \mathrm{ml}$ of hexane. Hundred microliters of $2 \mathrm{~N}$ $\mathrm{KOH}$ in methanol solution were added to the samples and vortexed for $2 \mathrm{~min}$. The mixture was then spun at $784 \mathrm{~g}$ for $1 \mathrm{~min}$. Sodium sulphate (anhydrous, $0.08 \mathrm{~g}$ ) was added to the samples, which were further centrifuged at $2180 \mathrm{~g}$ for $3 \mathrm{~min}$. The clear fraction was transferred into a vial for FFA analysis (NUDDA et al. 2005).

Fatty acid methyl esters (FAME) and CLA were determined by gas chromatography using a Finnigan Trace Ultra (Milan, Italy) gas chromatograph equipped with a HP 88 capillary column $(100 \mathrm{~m} \times 0.25 \mathrm{~mm}$ ID with $0.2 \mu \mathrm{m}$ film thickness; Agilent Technologies, Inc., Wilmington, DE, USA). Identification of FAME was carried out by mass spectrometry using a mass spectrometer (Finnigan Trace DSQ, Austin, TX, USA) set at $200^{\circ} \mathrm{C}$ of capillary direct interface temperature, $70 \mathrm{eV}$ ionization energy, 50-500 amu of mass interval and $500 \mathrm{amu} \mathrm{s}^{-1} \mathrm{scan}$ rate. Two microliters were injected in splitless mode $\left(200^{\circ} \mathrm{C}\right)$ by an autoinjector. Initial column temperature was $100^{\circ} \mathrm{C}$ and increased to $230^{\circ} \mathrm{C}$ in a 3 step up ramp procedure (Ramp 1: $20^{\circ} \mathrm{C} \mathrm{min}{ }^{-1}$ to $150^{\circ} \mathrm{C}$ held for $2 \mathrm{~min}$; Ramp 2: $10^{\circ} \mathrm{C} \mathrm{min}{ }^{-1}$ to $200^{\circ} \mathrm{C}$

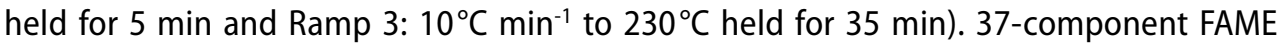


standard mixture (C4-C24; Supelco; Bellefonte, PA, USA) and CLA standards (Nu-Chek; Elysian, MN, USA) were used in the identification of FFA and CLA. The relative concentration of each FA was calculated by dividing its peak area by the total peak area of all the FA detected in the chromatogram and expressed as $\mathrm{g} \mathrm{FA} \mathrm{kg}^{-1}$ total analysed FA.

\section{Statistical analysis}

A repeated measurement analysis of variance was used for all the variables. The effects of period, age and period $\times$ age interactions were taken into account in the statistical model. The Tukey test was applied for the post hoc analyses. The data were analysed by SAS (1999) Statistical Package Programme. The data were presented as least square means.

\section{Results}

Body weight of goats was not affected $(P=0.1599)$ by sampling period. On the other hand, body condition score differed ( $P=0.0021)$ among the sampling periods (Table 2 ).

Table 2

Body weight, body condition score and milk composition and yield at different sampling periods of goats managed in a semi-intensive production system

Lebendgewicht, Körperkonditionspunkte, Milchinhalt und Milchleistung an unterschiedlichen Probetagen von Ziegen, die in einem semi-intensiven Produktionssystem gehalten wurden

\begin{tabular}{|c|c|c|c|c|c|c|c|c|c|}
\hline \multirow{2}{*}{ Parameter } & \multicolumn{2}{|c|}{ April, $n=20$} & \multicolumn{2}{|c|}{ June, $n=21$} & \multicolumn{2}{|c|}{ August, $n=16$} & \multicolumn{2}{|c|}{ October, $n=19$} & \multirow{2}{*}{$P$} \\
\hline & Mean & SE & Mean & SE & Mean & SE & Mean & SE & \\
\hline Body weight, kg & 55.4 & 1.54 & 58.0 & 1.56 & 57.5 & 1.60 & 56.4 & 1.43 & 0.1599 \\
\hline $\mathrm{BCS}$ & $2.64^{\mathrm{a}}$ & 0.077 & $2.78^{\mathrm{b}}$ & 0.078 & $2.83^{b}$ & 0.080 & $2.91^{\mathrm{b}}$ & 0.072 & 0.0021 \\
\hline Milk yield, kg day ${ }^{-1}$ & $3.21^{\mathrm{a}}$ & 0.123 & $2.17^{b}$ & 0.124 & $1.47^{c}$ & 0.131 & $0.95^{d}$ & 0.108 & 0.0001 \\
\hline Milk fat, $\%$ & $3.18^{\mathrm{a}}$ & 0.141 & $3.22^{\mathrm{a}}$ & 0.145 & $3.54^{\mathrm{b}}$ & 0.152 & $4.48^{\mathrm{c}}$ & 0.128 & 0.0001 \\
\hline$\left(\mathrm{g} \mathrm{day}^{-1}\right)$ & $99.6^{\mathrm{a}}$ & 4.54 & $69.0^{\mathrm{b}}$ & 4.59 & $51.7^{c}$ & 4.86 & $42.6^{c}$ & 4.00 & 0.0001 \\
\hline Milk lactose, $\%$ & $4.30^{\mathrm{a}}$ & 0.034 & $4.23^{\mathrm{a}}$ & 0.034 & $4.32^{\mathrm{a}}$ & 0.036 & $4.54^{\mathrm{b}}$ & 0.030 & 0.0001 \\
\hline$\left(\mathrm{g} \mathrm{day}^{-1}\right)$ & $139^{a}$ & 5.2 & $93^{b}$ & 5.2 & $63^{c}$ & 5.5 & $43^{d}$ & 4.5 & 0.0001 \\
\hline Milk protein, $\%$ & 3.10 & 0.026 & 3.07 & 0.027 & 3.06 & 0.027 & 3.12 & 0.023 & 0.1316 \\
\hline$\left(\mathrm{g} \mathrm{day}^{-1}\right)$ & $100^{\mathrm{a}}$ & 3.8 & $67^{b}$ & 3.8 & $45^{c}$ & 4.0 & $29^{d}$ & 3.3 & 0.0001 \\
\hline Milk SNF, \% & $8.16^{\mathrm{a}}$ & 0.062 & $8.09^{a}$ & 0.063 & $8.14^{\mathrm{a}}$ & 0.065 & $8.44^{\mathrm{b}}$ & 0.066 & 0.0001 \\
\hline$\left(\right.$ g day $\left.^{-1}\right)$ & $263.7^{\mathrm{a}}$ & 9.82 & $177.0^{\mathrm{b}}$ & 9.94 & $119.3^{c}$ & 10.5 & $79.7^{d}$ & 8.64 & 0.0001 \\
\hline
\end{tabular}

BCS body condition score, SNF solids-non-fat, SE standard error Means with different superscripts differ significantly $(P<0.05)$.

\section{Milk yield and composition}

Milk yield and composition of lactating goats at different sampling periods are presented in Table 2. Milk yield was affected $(P=0.0001)$ by sampling period, with the highest yield $(3.21 \mathrm{~kg})$ found in April. Milk fat concentration varied $(P=0.0001)$ throughout the lactation, with the highest value in October and the lowest during the period of highest yields in April and June. Milk fat yield also varied $(P=0.0001)$ as a consequence of changes in milk yield and fat concentration. Similar to milk fat, lactose concentration and yield varied $(P=0.0001)$, with the highest concentration obtained in October. Milk protein concentration was quite stable throughout the lactation, but milk protein yield changed $(P=0.0001)$ with the highest yield in April and the lowest in October, when milk yield was lowest in the present study. 


\section{Milk fatty acid composition}

Milk FA profiles of goats at different sampling periods are presented in Table 3. Under the given analytical conditions, butyric (C4:0), caproic (C6:0) and caprylic (C8:0) acids could not be determined due to the elution of these acids with solvent.

The most abundant FA was C16:0 followed by C18:1 n-9, C18:0, C10:0 and C14:0. The percentage of these FA accounted for about $88 \%$ of the total FA in milk of the goats in all sampling periods (Table 3 ). Palmitic acid ( $(16: 0)$ was not affected $(P=0.3572)$ by sampling period and accounted for an average of $28.4 \%$ of the total FA.

Oleic acid (C18:1 $n-9)$ showed a significant variation among the sampling periods $(P=0.0001)$, with the highest value in August and the lowest value in April. Similarly, stearic (C18:0; $P=0.0128)$, capric ( $C 10: 0 ; P=0.0001)$ and lauric (C12:0; $P=0.0014)$ acids varied significantly among the sampling periods and the greatest values were observed in April. On the other hand, miristic acid (C14:0) was not affected by the sampling periods $(P=0.4469)$.

Linoleic acid ( $C 18: 2)$ showed a variation $(P=0.0088)$ during the study, ranging from $2.7 \%$ in April to $4.1 \%$ of total FAME in June (Table 3). A similar variation was found in linolenic acid (C18:3) throughout the study. Two CLA isomers (18:2 C9, t11 and 18:2 t10, c12) were identified and presented together as total CLA (Table 3). The total CLA content ranged between $1.2 \%$ and $1.4 \%$ of total FAME and was not affected $(P=0.2448)$ by the sampling period.

Table 3

Milk fatty acid profiles at different sampling periods of goats managed under a semi-intensive production system Milchfettsäuren-Profil in unterschiedlichen Probetagen von Ziegen die in einem semi-intensiven Produktionssystem gehalten wurden

\begin{tabular}{|c|c|c|c|c|c|c|c|c|c|}
\hline \multirow{2}{*}{$\begin{array}{l}\text { Fatty acid, } \\
\mathrm{g} \mathrm{kg}^{-1} \text { FAME }\end{array}$} & \multicolumn{2}{|c|}{ April, $n=20$} & \multicolumn{2}{|c|}{ June, $n=21$} & \multicolumn{2}{|c|}{ August, $n=16$} & \multicolumn{2}{|c|}{ October, $n=19$} & \multirow{2}{*}{$P$} \\
\hline & Mean & SE & Mean & SE & Mean & SE & Mean & SE & \\
\hline C10:0 & $118^{\mathrm{a}}$ & 4.5 & $82^{b}$ & 4.6 & $87^{b}$ & 4.7 & $90^{b}$ & 4.0 & 0.0001 \\
\hline C12:0 & $51.5^{\mathrm{a}}$ & 2.64 & $37.8^{\mathrm{b}}$ & 2.70 & $39.3^{b}$ & 2.77 & $42.8^{b}$ & 2.36 & 0.0014 \\
\hline C14:0 & 105 & 4.9 & 95.0 & 5.03 & 105 & 5.2 & 99.3 & 4.39 & 0.4469 \\
\hline C15:0 & 7.80 & 1.135 & 9.88 & 1.163 & 10.0 & 1.19 & 9.32 & 1.014 & 0.4418 \\
\hline $\mathrm{C} 16: 0$ & 294 & 13.6 & 297 & 13.9 & 270 & 14.3 & 274 & 12.2 & 0.3572 \\
\hline C18:0 & $182^{\mathrm{a}}$ & 11.4 & $167^{a c}$ & 11.6 & $142^{b}$ & 11.8 & $151^{\mathrm{bc}}$ & 10.2 & 0.0128 \\
\hline C18:1 n-9 & $182^{\mathrm{a}}$ & 13.4 & $240^{\mathrm{b}}$ & 13.8 & $282^{c}$ & 14.1 & $266^{\mathrm{bc}}$ & 12.0 & 0.0001 \\
\hline C18:2 & $27.3^{a}$ & 2.90 & $41.1^{b}$ & 2.97 & $35.7^{b}$ & 3.04 & $35.2^{\mathrm{b}}$ & 2.59 & 0.0088 \\
\hline C18:3 & $10.1^{\mathrm{a}}$ & 0.70 & $9.88^{\mathrm{a}}$ & 0.706 & $5.52^{b}$ & 0.724 & $4.61^{b}$ & 0.616 & 0.0001 \\
\hline $\mathrm{CLA}$ & 13.5 & 1.13 & 11.5 & 1.15 & 13.2 & 1.18 & 14.0 & 1.02 & 0.2448 \\
\hline C20:0 & 5.41 & 0.763 & 5.78 & 0.776 & 7.17 & 0.792 & 6.79 & 0.686 & 0.1263 \\
\hline$C 20: 4$ & 2.22 & 0.269 & 3.05 & 0.276 & 2.84 & 0.283 & 2.80 & 0.240 & 0.1527 \\
\hline C21:0 & $0.76^{a}$ & 0.325 & $2.78^{b}$ & 0.333 & $0.70^{\mathrm{a}}$ & 0.342 & $0.77^{\mathrm{a}}$ & 0.291 & 0.0001 \\
\hline C22:0 & $1.29^{\mathrm{a}}$ & 0.372 & $2.51^{\mathrm{b}}$ & 0.380 & $3.29^{b}$ & 0.389 & $3.41^{b}$ & 0.332 & 0.0001 \\
\hline MCFA & $275^{\mathrm{a}}$ & 9.3 & $215^{\mathrm{b}}$ & 9.6 & $232^{\mathrm{b}}$ & 9.8 & $231^{\mathrm{b}}$ & 8.3 & 0.0001 \\
\hline SFA & $759^{a}$ & 16.0 & $686^{b}$ & 16.4 & $653^{b}$ & 16.8 & $670^{b}$ & 14.0 & 0.0001 \\
\hline UFA & $235^{a}$ & 15.8 & $305^{b}$ & 16.2 & $339^{b}$ & 16.6 & $322^{\mathrm{b}}$ & 14.2 & 0.0001 \\
\hline PUFA & 53.2 & 4.04 & 65.4 & 4.14 & 57.1 & 4.24 & 56.6 & 3.61 & 0.1233 \\
\hline
\end{tabular}

FAME FA methyl esters, CLA conjugated linoleic acid $(C 18: 2 \quad c 9, t 11+t 10, c 12)$, MCFA medium-chain FA $(C 10: 0+C 12: 0+C 14: 0)$, SFA saturated FA (C10:0+C12:0+C14:0+C15:0+C16:0+C18:0+C20:0+C21:0+C22:0), UFA unsaturated FA $(C 18: 1+C 18: 2+C 18: 3+C 20: 4+C L A)$, PUFA polyunsaturated FA $(C 18: 2+C 18: 3+C 20: 4+C L A)$, SE standard error Means with different superscripts differ significantly $(P<0.05)$. 
There was a variation ( $P=0.0001)$ in the medium chain $\mathrm{FA}(\mathrm{C} 10: 0$ and $\mathrm{C} 12: 0)$ concentration of milk fat of the goats among the sampling periods of the present study, with the highest value found in April (Table 3). Likewise saturated FA (C10:0-C22:0) fluctuated $(P=0.0001)$ during lactation, depending upon the sampling period, April having the highest concentration. The percentage of unsaturated FA (UFA; C18:1-C20:4 including CLA) was $(P=0.0001)$ lower in April than at other sampling periods. On the other hand, no difference in poly-UFA (PUFA; C18:2-C20:4 including CLA) of milk fat, varying between $5.3 \%$ in April and $6.5 \%$ of total FAME in June, was determined among the sampling periods in the present study (Table 3 ).

\section{Discussion}

The purpose of the present study was to determine changes in the FA profile of goats' milk throughout lactation. The husbandry of goats was based on a semi-intensive production system consisting of grazing on a woody and herbaceous pasture with the supplementation of mixed concentrate and vetch hay. Milk sampling was carried out at periods when considerable changes in the nutrient composition of the pasture occurred (see Table 1).

Milk yield varied significantly by 2.26 I during the lactation. Milk fat concentration was lowest when the milk yield was at the highest in April (Table 3). This can be attributed to the dilution effect due to the greater amount of milk produced in April (LOCK \& GARNSWORTHY 2003). A similar explanation can also put forward for observed changes in milk solids-non-fat, lactose and protein yields.

Short- and medium-chain FA (SMCFA; C4-C14) are synthesised de novo from acetate by the mammary glands in ruminants, whereas long-chain FA $(L C F A ; \geq C 16)$ are transported in blood to the mammary glands (DEMEYER and DOREAU 1999). Although factors affecting de novo synthesis of FA are not fully understood (LOCK and GARNSWORTHY 2003), the rate of SMCFA synthesis depends on the rate and amount of LCFA provided to the mammary glands in blood (DEMEYER and DOREAU 1999). The proportions of SMCFA and LCFA in milk fat are also closely related with physiological and nutritional conditions of ruminants (CHILLARD et al. 2003). In the present study, highest percentages of medium chain FA (C10:0 and C12:0) were found in April (Table 3). Although C18:0 was relatively higher in the same period than in others, $\mathrm{C} 18: 1 n-9$ and $\mathrm{C} 18: 2$ were at the lowest. Higher concentrations of C10:0 and C12:0 in April may be explained by the delivery of lower amounts of LCFA to the mammary glands. In later periods of lactation, the proportion of LCFA in milk fat increased significantly. In contrast, significant decreases in C10:0 and C12:0 occurred, indicating less de novo synthesis of these FA by the mammary glands. Using dispersed epithelial cells of goat mammary glands, HANSEN and KNUDSEN (1987) demonstrated that de novo synthesis of FA from acetate is inhibited by LCFA.

TSIPLAKOU et al. (2006) found a significant variation in milk CLA content of sheep grazing on natural pasture during a lactation period between January and June, whereas milk CLA contents of goats browsing on trees and shrubs did not exhibit any significant change. These authors assumed that the difference in CLA contents of sheep and goat milk depends most probably on their grazing ecology. Sheep graze largely on grass 
pasture, whereas goats browse on trees and bushes. Grass is rich in linoleic and linolenic acids, which are the substrates for CLA production (GRIINARI and BAUMAN 1999). Similarly, the milk CLA content of goats browsing on trees and bushes may be related with the chemical and botanical composition of the pastures and their subsequent effects on the composition and activity of microorganisms involved in the biohydrogenation process (GRIINARI and BAUMAN 1999). Recent evidence, for example, suggests that the terminal step of ruminal $\alpha$-linoleic acid biohydrogenation is inhibited by condensed tannins (KHIAOSA-ARD et al. 2009), which are present at significant concentrations in most shrubs and trees (DECANDIA et al. 2000), which were the components of the natural pasture in the present study. In the present study, the CLA content of milk fat did not vary significantly throughout the lactation, which is in favour of the findings of TSIPLAKOU et al. (2006). In contrast, the CLA content of goats milk grazing on a $60 \%$ Leguminosae and $40 \%$ grass pasture fluctuated significantly during lactation (D'URSO et al. 2008). The difference in milk CLA content of goats between the studies of TSIPLAKOU et al. (2006) and D'URSO et al. (2008) can be attributed to variations in botanical and chemical (especially PUFA) compositions of the pastures grazed by the goats.

Rumenic acid $(C 18: 2 C 9, t 11)$ constitutes 75 to $90 \%$ of CLA isomers and may possess beneficial effects on health (GRIINARI and BAUMAN 2003). The t10, C12 CLA is another isomer that has been shown to cause milk fat depression in cows (BAUMAN and GRIINARI 2003). This isomer was not identified in the milk fat of goats kept under semi-intensive conditions (TSIPLAKOU et al. 2006). However, a FA peak corresponding to t10, c12 CLA was found in milk fat samples in the present study. The presence or absence of the isomer in the milk fat of goats may probably be associated with genetic factors (breed) or the activity of bacteria responsible for the production of CLA $t 10, C 12$ in the rumen. There is also no evidence yet of endogenous synthesis of $t 10, C 12$ CLA by the mammary glands (TSIPLAKOU et al. 2006).

The C18:0 content of ruminant feeds is low (DOREAU and CHILLARD 1997). Elevated concentration of this FA in milk compared with that in the diet is a consequence of extensive biohydrogenation of (P)UFA by the microorganisms in the rumen (GRIINARI and BAUMAN 2003). Variation in the C18:0 content of milk depends on various factors such as the amount of PUFA in the diet, biohydrogenation processes in the rumen and $\triangle 9$-desaturase activity in the mammary glands (DEMEYER and DOREAU 1999). It was reported that $40 \%$ of the C18:0 extracted from the blood into the mammary glands is converted to C18:1 n-9 in order to preserve the fluidity of milk (CHILLARD et al. 2000). The C18:0 content was highest in April, and then decreased significantly throughout the lactation (Table 3). The decrease in the C18:0 content of milk fat can be due to a reduction in the efficiency of biohydrogenation or an increase in $\triangle 9$-desaturase activity in the mammary glands (LOCK and GARNSWORTHY 2003). TSIPLAKOU et al. (2006) analysed goat milk of flocks grazing on a woody pasture and found higher mean values of C18:0 ranging from 14 to $24 \%$ than those of the same FA varying from 14 to $18 \%$ in the current study.

In ruminants, CLA is synthesised from linoleic and linolenic acids by ruminal bacteria (KEPLER and TOVE 1967). The metabolism of these FA in the rumen is of fundamental importance to the composition of ruminant products and is largely influenced by factors related to the composition of the actual diet consumed by the animal, including rumen 
environment and bacterial population (GRIINARI and BAUMAN 1999). A significant variation was found in C18:2 and C18:3 contents of milk fat during the current study (Table 3). This variation can be attributed to the changes in the extent of biohydrogenation of C18:2 and C18:3, which is influenced by the composition and activity of microorganisms in the rumen rather than their dietary intake. In the current study, the mean values of C18:2 ranged from 2.7 to $4.1 \%$ of the total FAME during lactation, which were similar or greater than the values reported for highland and mountain flocks ( $2.8 \%$ and $2.4 \%$; ZAN et al. 2006 and $2.5 \%$ for goat flocks on native pasture; TSIPLAKOU et al. 2006). The quantities of C18:3 (expressed as percentage of total FAME) in our study were similar ( $0.78 \%$ on average) to those $(0.88 \%$ - highland flock; $0.83 \%$ - mountain flock) reported by Zan et al. (2006).

The present study suggests that the FA composition of goat milk shows variations, depending upon FA and stage of lactation. Unlike the results of TSIPLAKOU et al. (2006), who found CLA (C18:2 t10, $c 12)$ in sheep but not in goats under semi-intensive conditions, the detection of the isomer in the milk of goats of this study is of particular interest since this CLA isomer is known to inhibit milk fat synthesis (BAUMAN and GRIINARI 2003) and deserves investigation.

\section{Acknowledgements}

Authors thank Mr. M. Seçkin Aday, Mrs. Hande Işıl Akbağ and Mr. Cemil Tölü for their technical assistance. The authors are also grateful to Prof. T. Savaş for statistical analysis of the data and to Prof. K.-H. Südekum for his precious comments and suggestions. This study was funded by the Scientific Research Projects Commission of Çanakkale Onsekiz Mart University (Project No: 2006/17).

\section{References}

Association of Official Analytical Chemists (AOAC) (2000) Official Methods for Analysis of the Association of Official Analytical Chemists, 17th ed. Gaithersburg, MD, USA.

Bauman DE, Griinari JM (2003) Nutritional regulation of milk fat synthesis. Annu Rev Nutr 23, 203-27

Chilliard Y, Ferlay A (2004) Dietary lipids and forage interactions on cow and goat milk fatty acid composition and sensory properties. Reprod Nutr Dev 45, 467-492

Chilliard Y, Ferlay A, Mansbridge RM, Doreau M (2000) Ruminant milk fat plasticity: nutritional control of saturated, polyunsaturated, trans and conjugated fatty acids. Annales de Zootechnie 49, 181-205

Chilliard Y, Ferlay A, Rouel J, Lamberet G (2003) A review of nutritional and physiological factors affecting goat milk lipid synthesis and lipolysis. J Dairy Sci 86, 1751-70

Decandia M, Sitzia M, Cabiddu A, Kababya D, Molle G (2000) The use of polyethylene glycol to reduce the anti-nutritional effects of tannins in goats fed woody species. Small Rumin Res 38, 157-64

Demeyer D, Doreau M (1999) Targets and procedures for altering meat and milk lipids. Proc Nutr Soc 58, 593-607

Doreau M, Chilliard Y (1997) Digestion and metabolism of dietary fat in farm animals. Br J Nutr 78, S15-S35

Doyon A, Ridorossi C, Chouinard PY (2004) Milk yield and composition in dairy goats fed different levels of extruded soybeans. J Anim Feed Sci 13, 685-8

D'Urso S, Cutrignelli MI, Calabro S, Bovera F, Tudisco R, Piccolo V, Infascelli F (2008) Influence of pasture on fatty acid profile of goat milk. J Anim Physiol Anim Nutr 92, 405-10

Feng S, Lock AL, Garnsworthy PC (2004) Technical Note: A rapid lipid separation method for determining fatty acid composition of milk. J Dairy Sci 87, 3785-8

Gorecki MT, Wojtowski J, Kaczmarek P, Dankow R, Cais-Sokolinska D, Nowak KW (2004) Concentrations of progesterone and $17 \beta$-estradiol in blood and milk and those of natural inhibitors in milk of goats in various physiological stages. Arch Tierz $47 \mathrm{SI}, 90-6$ 
Griinari JM, Bauman DE (1999) Biosynthesis of conjugated linoleic acid and its incorporation into meat and milk in ruminants. In: Yurawecz MO, Mossoba MM, Kramer JKG, Pariza MW, Nelson GJ (eds) Advances in Conjugated Linoleic Acid Research, Vol. 1, AOCS Press, Champaign, IL, 180-220

Griinari JM, Bauman DE (2003) Update on theories of diet-induced milk fat depression and potential applications. In: Garnsworthy PC, Wiseman J (eds) Recent Advances in Animal Nutrition, Nottingham University Press, UK, 115-156

Hansen HO, Knudsen J (1987) Effect of exogenous long-chain fatty acids on lipid biosynthesis in dispersed ruminant mammary gland epithelial cells: Esterification of long-chain exogenous fatty acids. J Dairy Sci 70, 1344-9

Kepler CR, Tove SB (1967) Biohydrogenation of unsaturated fatty acids: III. Purification and properties of a linoeate delta-12-cis, delta-11-trans-isomerase from Butyrivibrio fibrisolvens. J Biol Chem 242, 5686-92

Leibetseder J (1996) Influence on the composition of animal fat by nutrition. Arch Tierz 39, 333-45 [in German]

Lock AL, Garnsworthy PC (2003) Seasonal variation in milk conjugated linoleic acid and $\Delta 9$-desaturase activity in dairy cows. Livest Prod Sci 79, 47-59

Luna P, Juarez M, De la Funte MA (2005) Validation of a rapid milk fat separation method to determine the fatty acid profile by gas chromatography. J Dairy Sci 88, 3377-81

Makkar HPS, Blümmel M, Becker K (1995) Formation of complexes between polyvinyl pyrrolidones or polyethylene glycols and their implication in gas production and true digestibility in vitro techniques. Br J Nutr, 73, 897-913

Mir Z, Goonewardene LA, Okine E, Jaeger S, Scheer HD (1999) Effect of feeding canola oil on constituents, conjugated linoleic acid (CLA), and long chain fatty acids in goats milk. Small Rumin Res 33, 137-43

Morand-Fehr P, Fedele V, Decandia M, Le Frileux Y (2007) Influence of farming and feeding systems on composition and quality of goat and sheep milk. Small Rumin Res 68, 20-34

Nudda A, McGuire MA, Battacone G, Pulina G (2005) Seasonal variation in conjugated linoleic acid and vaccenic acid in milk fat of sheep and its transfer to cheese and ricotta. J Dairy Sci 88, 1311-19

Nudda A, Usai MG, Mulas S, Pulina, G (2003) Utilization of extruded linseed cakes to modify fatty acid composition and increase CLA contents in goat milk. In: Proceeding of 54th Annual Meeting of European Association for Animal Production, Rome, Italy, 119

Pfeuffer M (2001) Physiological effects of individual fatty acids in animals and human body, with particular attention to coronary heart disease risk modulation. Arch Tierz 44, 89-98

SAS, 1999. SAS Online Doc, Version 8.0. SAS Institute, Cary, NC.

Tsiplakou E, Mountzouris KC, Zervas G (2006) Concentration of conjugated linoleic acid in grazing sheep and goat milk fat. Livest Sci 103, 74-84

Van Soest PJ, Robertson JB, Lewis BA (1991) Methods for dietary fiber, neutral detergent fiber, and nonstarch polysaccharides in relation to animal nutrition. J Dairy Sci 74, 3583-97

Walisiewicz-Niedbalska W, Patkowska-Sokola B, Bodkowski R, Rozycki K (2004) The influence of linoleic acid and its isomers in goat diet on the composition of fatty acid in goat milk fat. Arch Tierz $47 \mathrm{SI}$, 103-07

Wojtowski J, Dankow R, Gut A, Pikul J, Slosarz P, Stanisz M, Steppa R (2001) Fatty acid composition and cholesterol content of sheep and goat milk fat during lactation. Arch Tierz $44 \mathrm{SI}, 299-308$

Zan M, Stibilj V, Rogelj I (2006) Fatty acid composition of goats grazing on alpine pasture. Small Rumin Res $64,45-52$

Received 8 April 2009, accepted 4 August 2009.

Corresponding author:

Assoc. Prof. Dr. CENGIZ ATAŞOĞLU

email: catasoglu@comu.edu.tr

Department of Animal Science, Faculty of Agriculture, Çanakkale Onsekiz Mart University, 17020,

Çanakkale, Turkey 